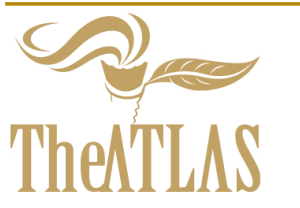

\title{
From Instrumental Research in Art to its Sharing: Producing a Commons, Respecting the Singular
}

Samuel Bianchini, École Nationale Supérieure des Arts Décoratifs - Paris (EnsAD) / PSL Research University, Paris, Email: sb@dispotheque.org

Received 18 December 2017; Revised 25 December 2017; Accepted 29 Demeber 2017

Copyright (C)2017 Samuel Bianchini. This is an open access article distributed under the Creative Commons Attribution License (https://creativecommons.org/licenses/by/4.0/), which permits unrestricted use, distribution, and reproduction in any medium, provided the original work is properly cited.

Available online 17 January 2018 at www.atlas-journal.org, doi: 10.22545/2017/00094

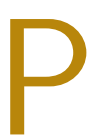

ractice-based research in art and design, or "Research 8 Creation" ("Recherche 85 Creation" in French-speaking countries), is developing rapidly. Questioning the new relationships between artistic practices and academic research (as well as industrial) also leads to rethinking methods of cooperation and sharing between the arts and scientific disciplines. Based on an instrumental and even "organological" (after Gilbert Simondon and Bernard Stiegler) approach, research in art is examined here through the prism of "allographic" principles borrowed from Nelson Goodman, and then illustrated through several works. Subsequently, the fundamental as well as practical scope of such an instrumental and allographic model is demonstrated. Such a model in fact offers a solid base for the organization of a multidisciplinary team (which requires a redistribution of egos); for publishing and economic development strategies of various forms; as well as for a rethinking of the production of a commons whose methods of construction are based above all on the development of means that make the sharing of practices possible. Keywords: Rechearch \& creation, allographs, instrumental, distributed authority, art transfer.

\section{Introduction}

While practice-based research in art and design - or, in French-speaking countries, "Recherche \& Création" ${ }^{1}$ or more simply "recherche-création" ${ }^{2}$ -

${ }^{1}$ Though originally seen from an instructional angle, "Recherche et Création" was introduced into French art schools through the Ateliers de recherches et création ("arcs" - research and creation workshops) instituted by Jacques Imbert [1]. It was as part of that dynamic that I edited a book on the subject [2]. We retain the term "Research \& Creation" here, with an ampersand that helps identify the expression and at the same time reinforce the difference as well as the relationship between the two terms.

${ }^{2}$ This is the formulation preferred in Québec. Cf. for example: the conference La recherche-création : territoire 
is currently developing strongly, numerous questions remain: What is research in a school of art and design today? Why develop it and what purpose can it serve? What can a research approach, and what's more a doctorate, provide an artist? What are the pitfalls of such an approach? Why is creating not research, and vice-versa? How to posit a research question in line with academic criteria as well as artistic expectations? How to include that research in an established academic context? What is that context? Can it be changed? How to develop such research, in practice and in theory? What is practice-based research? How best to link practice and theory? What position to accord technology? What methods can serve as references, to be applied, adapted, or reinvented? Why work collectively rather than individually, and what do we have to gain and to lose? How do we organize ourselves, collectively and individually? How do we cooperate with other disciplines, in particular scientific ones (experimental sciences, human sciences, engineering sciences, etc.)? What can they offer us? What can we offer them? How to conceive of research in partnership with the private sector and even industry? How to enhance the value work produced in "Research \& Creation"? What does publishing mean for a creator engaged in research?

\section{Practice Based Research in Art: an Instrumental Research}

Developing research in art and design indeed presents numerous questions, whether they be related to training in research and through research (in other words the supervision of student-researchers), to the development of research work (involving a team), or to the structuring of research (on an institutional level). As such research increases in our establishments a reality that also questions those who are already

d'innovation méthodologique, organized by Louise Poissant, Jean Dubois, and Gisèle Trudel, Université du Québec à Montréal (UQAM), 19, 20 and 21 March 2014; Media Art Histories 2015, on the theme "RE-CREATE", organized by Hexagram, under the direction of Chris Salter (Concordia University) and Gisèle Trudel (Université du Québec à Montréal), Montréal, from 5 to 8 November 2015, addressing these issues with particular attention to their historical origins; and les États Généraux de la recherche-création, from 24 to 26 May 2016, organized by Université Laval, Québec, by Sophie Stévance (Canada Research Chair in Research-Creation in Music, Université Laval). engaged in the approach - publications addressing these questions are naturally more and more numerous. Indeed, it is not surprising to note that the first publications of reference on the subject were presented by the individuals directly involved in the development of such research - for example Bruce Archer [3] and Alain Findeli and Anne Coste [4] in the institutions and countries concerned from the start, including the Royal College of Art in London [5] and various universities in Quebec [6]. The case of France is distinct: although design (which must be understood here as an "applied art") was long neglected with regard to research, ${ }^{3}$ the fine arts have been present in universities, and therefore in research, since $1968 .{ }^{4}$ Some methodological writings have therefore been produced by colleagues dedicated to better establishing fine arts research in the university. ${ }^{5}$ While those writings insist on the need for a connection between practice and theory, they nevertheless remain reluctant to propose clear methodologies and objectives with regard to practice. One must certainly refrain from proposing principles too easily transformed into rules, which

${ }^{3}$ Even though, in recent years, some French and France-based researchers have become more involved in questions relative to design, such as David Bihanic, Marie-Ange Brayer, Claire Brunet, Francesca Cozzolino, Sophie Fétro, Catherine Geel, Annie Gentes, Pierre-Damien Huyghe, Roxane Jubert, Annick Lantenois, Anthony Masure, Alexandra Midal, Nicolas Nova, Sophie Pène, Olivier Peyricot, Emanuele Quinz, Gilles Rouffineau and Stéphane Vial, most of them are not practitioners. We recall on this issue the recent conference on the subject: La recherche en design, un enjeu pour Paris-Saclay, organized by the École normale supérieure of Cachan, 15 and 16 October 2014.

${ }^{4}$ In particular at Université Paris 8 - Vincennes - Saint-Denis, where Frank Popper created the first Fine Arts department in 1969, following, among other events, the cultural upheaval of 1968. Popper became head of the department in the fall of 1969. Jean-Louis Boissier participated alongside Frank Popper as early as 1969 in establishing the department. Reading the archives on a dedicated website [7] is profitable as is this book [8].

${ }^{5}$ It is surely Jean Lancri (at the time professor at Université Paris 1 Panthéon-Sorbonne) who was able to crystalize this academic approach with his text that is cited very frequently, including by researchers in Quebec [9]. Other academics have also contributed to better defining research in art in the context of French universities, including Jean Da Silva [10]. One approach often put forward by academic researchers, not unrelated to our proposals, consists of designating "poiesis" as a field of research in art, following the route opened, in particular, by René Passeron [11], pursuant to Paul Valéry. 
would be contradictory to artistic activity itself. ${ }^{6}$ However, it is difficult to base oneself on those texts in building one's own practical path. The texts also suffer, quite often, from being based on the dearth of practice inherent to French universities, which struggle to support their art departments within their humanities and social science faculties, those not being materially or organizationally adapted, when the arts and design should be endowed with means similar to those provided for the engineering and experimental sciences. We must recall that in France it was above all music and sound research, and even, more broadly, audiovisual research, that opened the way for research in direct contact with creation, and that as early as 1943, under the impetus of Pierre Schaeffer (with the creation of the studio d'essai within the public broadcaster Radiodiffusion franaise, RDF), of the GRMC (Groupe de recherche de musique concrte, in 1951) which became the GRM (Groupe de recherche musicale, in 1958) and would later spread throughout France, and then of Pierre Boulez (in particular with the $\left.\operatorname{Ircam}^{7}\right){ }^{8}$

That we are immediately led to position research in art and design with respect to the engineering sciences, the natural sciences, or music, may not be accidental. All of those fields give pride of place to "instruments", ${ }^{9}$ whether the term be understood in the musical sense or more broadly in its scientific context. As in those other disciplines - and for myself, confronted in my laboratory, EnsadLab, with the need to organize my team and manage

\footnotetext{
${ }^{6}$ Perhaps we could still adopt this 18th-century Chinese approach: "The foundation of the One Brush Method resides in the absence of rules that engender the Rule; and the Rule thus obtained embraces the multiplicity of rules." [12].

${ }^{7}$ The terminology "research and creation" was probably first used at the IRCAM, which gave it an instrumental scope [13]. It is not unrelated to our own developments and those of Bernard Stiegler on organology, initiated when he was director of the institution.

${ }^{8}$ We should also mention the Acroe, Association pour la création et la recherche sur les outils d'expression, founded in 1976, which is fully part of an instrumental research that was, here again, first oriented toward music.

${ }^{9}$ Even if this approach is only rarely advanced in the experimental sciences, it is preponderant. See on this subject Bruno Latour's comments on "the presence of instruments", the place these means occupy in science - comments we take as our own, in the artistic field this time. For example, for the techniques, devices, apparatuses, and other means of inscription that can be "made into instruments" [14], pp. 42-45 and p. 49. of the downloadable version.
}

student-researchers - this instrumental dimension has emerged as a particularly structuring asset and a lever for the development of practice-based research in art, or, in other words, as a way of doing Research \& Creation.

Indeed, it is in that way that the meaning of Research \& Creation has already been supported and somewhat modeled [15], while retaining its essential openness and its societal significance, confirmed by Bernard Stiegler's organological approach [16]. ${ }^{10}$ In summary: the research dimension in Research \& Creation projects is primarily devoted to means rather than ends. Research in art is therefore part of a process that can be described as "instrumental research", to the extent that we consider the instrumental dimension in its broadest sense: concerning not only objects made to be used and to allow for operations, but also what is related to processes associated with those objects and other devices, or even more conceptual ways of working. Research, being instrumental, would therefore be focused on means and techniques, and creation on ends, on works of various kinds. It is undoubtedly too radical to separate means and ends in this way, and even to use those terms; however, we allow ourselves the liberty in order to lay the simple and pragmatic foundations that we will go on to refine afterwards. It should also be noted that, though we are developing Research \& Creation through this approach in our context, ${ }^{11}$ we do not pretend to reduce the ensemble of the field to that framework. The more general definitions of research-creation, such as those proposed by the Social Sciences and Humanities Research Council of Canada, ${ }^{12}$ as well as the Fonds de recherche du Québec Société et culture, ${ }^{13}$ suit

\footnotetext{
${ }^{10}$ Here, p. 173 . See also the colloquium we organized with Bernard Stiegler on the subject: L'organogense. Pour un nouveau paradigme de recherche en art et en design, international colloquium, 15 and 16 October 2015, École nationale supérieure des Arts Décoratifs, Paris. Program and videos available at: http://www.ensadlab.fr/fr/lorganogenese [last accessed 15 July 2017].

${ }^{11}$ Within the Reflective Interaction Research Group of EnsadLab, the laboratory of the École nationale supérieure des Arts Décoratifs - PSL Research University, Paris; including for our doctoral students in the SACRe program of PSL: "Sciences Arts Création Recherche".

${ }^{12}$ See the definition of research-creation: http://www.sshrccrsh.gc.ca/funding-financement/programsprogrammes/definitions-fra.aspx\#a25 [last accessed 15 July 2017]
}

${ }^{13}$ See the definition of research-creation: 
us all the more because they include our position without difficulty. That position, however, must be understood as having a particular aim: we wish to develop "practice-based" Research \& Creation by and for practice, ${ }^{14}$ at a school of art and design that trains artists and designers above all, not theorists, educators, or mediators of art and design.

Aside from the fact that it is too simplistic, the "research/means - creation/ends" conception could mislead in two ways, implying both that time accorded to research and time accorded to creation are distinct, and that they are consecutive, the first leading to the second. While the distinction is worth preserving, the consecutive relationship absolutely is not. On the contrary, the relationship between means and ends is not fixed. Continual back-andforth interactions are the proof of a subtle relationship between means and ends, in an experimental and iterative dynamic; far from being marginal in Research \& Creation, that way of doing things is in fact a very common process. While the distinction between research and creation needs to be refined ${ }^{15}$ in particular in the relationships between art and technology - it is nonetheless valuable and makes it possible to respond to many organizational and methodological questions that have institutional consequences.

http://www.frqsc.gouv.qc.ca/bourses-et-

subventions/consulter-les-programmes-remplir-unedemande/bourse/appui-a-la-recherche-creation-concoursautomne-2016-5aeb9wba1466537413107 [last accessed 15 July 2017]

${ }^{14}$ Though we make reference here to the categories proposed by Christopher Frayling - Research into or through or for art and design (in Op. Cit.), we nonetheless depart from it by considering the necessary link between by and for art, which is to say aiming for research by art that obtains results for art. That objective ("for art") is not, then, an end in itself, but must catalyze research, obliterate it the better to revive it, introducing an iterative dynamic between means and ends and thus avoiding lapsing into the principle of art for art's sake.

${ }^{15}$ It will be understood, then, that if the distinction between means and ends is necessary for establishing a clear and pragmatic methodology, their iterative and subtle relationship, and the chosen angle of approach, such as that of research (for which the means are also an end), can enable a reshuffling of the cards, as Bruno Latour does [17].

\section{Research \& Creation through the Notion of Allographic Arts}

To pursue that refining, it is useful to look to Nelson Goodman's theses about the so-called "allographic" arts, because our conception of Research \& Creation argues in favor of a two-stage art, or rather one with two types of "manifestations", or two states. Let us return briefly to that concept proposed by Nelson Goodman [18] [19]. The "allographic" notion was initially proposed in a context that does not, a priori, have much in common with ours, but it is useful for us and we would like to extend it in a direction that will enable us to develop it to the benefit of our methodology. Allographic art ${ }^{16}$ is defined by an ideal form of notation distinct from the final form the work takes. Thus, the execution of a musical score makes the art work, and as long as the score is respected, there is a work, which is unfakable because replicable at will. While there is a work at the moment of its instantiation, for that to take place, it must be prepared, conditioned, formalized, and specified through notation. That notation, or spelling, is itself dependent on an established language that makes possible an "orthographic" 17 relationship to the work, which is to say one that validates the respectful execution of that notation during its instantiation. ${ }^{18}$ There is a stage for the

\footnotetext{
${ }^{16}$ It should be noted that the synthesis we are attempting is not that simple, since Nelson Goodman himself progressively developed that dual autographic/allographic regime, first in his work Languages of Art: An Approach to a Theory of Symbols [18], pp. 112-123, and then coming back to it and adding precisions and nuances in a subsequent publication, Of Mind and Other Matters [19], pp. 139-145. It is in that second book that he states that the two stages that might characterize an allographic art are perhaps not necessary in certain cases and that one can qualify the two stages as "execution" and "implementation". Implementation would, briefly, be a matter of setting the work in operation in public. I myself proposed considering a third "actographic" regime, when execution and implementation are done with the public, or more broadly the context, which updates, instantiates the work so that it works, so that it occurs [20].

${ }^{17}$ The word "orthographic" is the one used by the French translator of Nelson Goodman's Languages of Art [18], Jacques Morizot, with the first reference on page 152 of the French version. In lieu of Goodman's original "spelling" and "correct spelling", we take the liberty of preserving the translated "orthographic" in English, as it seems particularly charged with meaning when used to describe the integrity of the execution of an allographic work.

${ }^{18}$ Nelson Goodman, Languages of Art [18], Op. Cit., p.121.
} 
ideal formalization (notation) and a stage for the instantiation. While those stages often occur in that order, they can also be ordered inversely, as when one produces notation from a musical improvisation, or, more broadly, from an experiment.

Though our synthesis is inevitably too brief, we nonetheless retain the principle of an art founded on that dual form, and, beyond a state of only notation, we suppose what is more broadly a moment of instrumental research and preparation. That stage of work can lead to specifications. ${ }^{19}$

But, for research in art, the instrumental conditions are not necessarily respectful of established protocols: they are themselves the object of redefinition or research for one or several original instantiations. One does not play with the rules of an established instrumentarium, but one can reinvent it and its mode of instantiation, at least in part.

Though we take some liberties with the allographic principle itself, based on a conventional notation allowing for an orthographic interpretation, let us nonetheless return to several constituent points of that regime likely to enrich our approach. In addition to the two-step staging (regardless of the order) that we appropriate, albeit with the "instrument/work" pair, two other aspects specific to the allographic regime converge with our approach: the first stage can give rise to specifications, and, for that reason, it allows for collective work.

Indeed, Nelson Goodman returned several times to two salient points of allographic works:

"Where the works are transitory, as in singing and reciting, or require many persons for their production, as in architecture and symphonic music, a notation may be devised in order to transcend the limitations of time and the individual." 20

If, for Nelson Goodman, the "notation/instantiation" relationship implies an ephemeral execution, it also allows for collaboration in the execution, thanks to a system of notation shared according to established conventions.

\footnotetext{
${ }^{19}$ Nelson Goodman himself integrated that possibility of notation: "Any building that conforms to the plans and specifications...", Idem, p. 120.

${ }^{20}$ Idem p. 121. Then the same idea is repeated on the next page of the same book, and again in Of Mind and Other Matters [19], p. 140.
}

If, more broadly, it is an instrumental regime that we retain in the first stage, it can also be shared according to clarified means of description and specification, and therefore allow for cooperative or collaborative work in the place of instrumental research. Such collective work, propelled by a shared interest and by shared protocols and specifications, can be multidisciplinary, for example permitting a convergence between an instrumental approach typical of the engineering or experimental sciences (physics, chemistry, biology...) and another from the domain of art. Not only is the collective character of research thus made possible, including for the arts, but it is most often necessary, because this instrumental research is complex, rarely conceivable at the level of the individual or of a single discipline.

Finally, and this is a return to the source of the allographic, this regime is built on a principle: "the unfakable". ${ }^{21}$ Indeed, since the work is an instantiation, any instantiation consistent with the notation is an execution of the work, and any duplication of the notation that is spelled correctly is of the same value. Thus, with notation and work duplicable at will, faking has no meaning. Formalization as notation indeed allows for execution. However, is this not also the basis of the patent, which is kept secret, and of the public license, which must remain public? Indeed, the basic principle of a patent or public license consists of a precise description of a process (a technique, an apparatus, an instrument, etc.) allowing for its execution by any person skilled in the art. It is on the basis of a specification equivalent to notation that the object of the patent or public license can be produced. In other words, what makes forgery impossible in the case of allographic art is, for the same reason, what must be protected in the case of a patent or public license. And it is for that reason that we can go beyond the notion of notation by extending it to all forms of specification. Any instrumental approach, including artistic, if it is original and specified as it should be, can benefit from legal protection and a transfer for possible use, artistic or non-artistic. Any economic advantage then relates to the instrumentarium, the object of the research stage that is independent of the creation that uses the instruments. And those latter, stimulated by artistic creation, initially for that creation, can give

\footnotetext{
${ }^{21}$ This is even the title of a sub-section of the work Languages of Art [18] in which Nelson Goodman developed the notions of autographic and allographic, Idem. p. 112.
} 


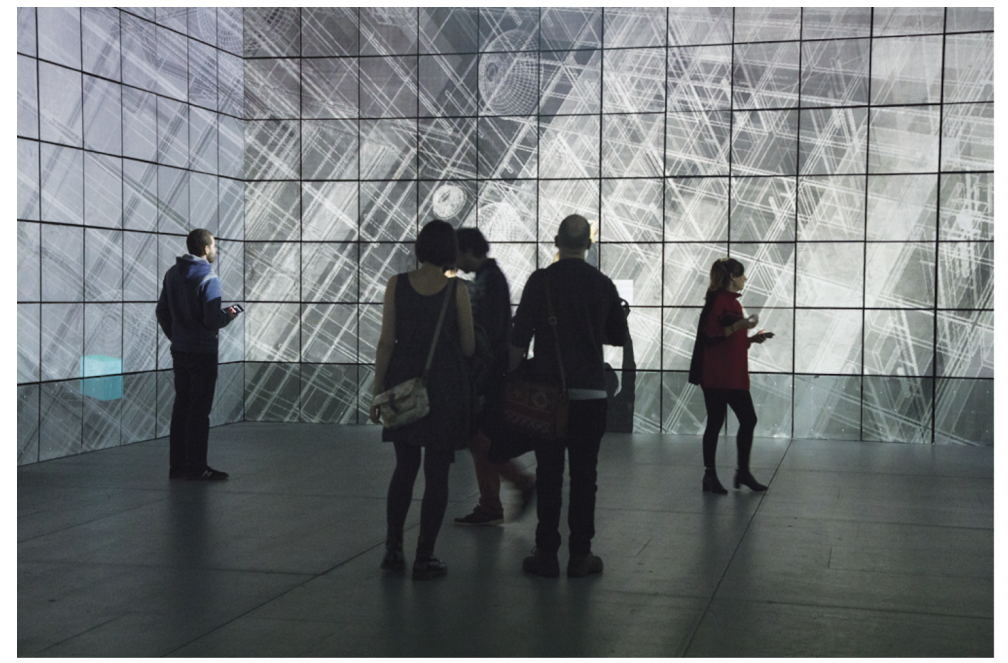

(a)

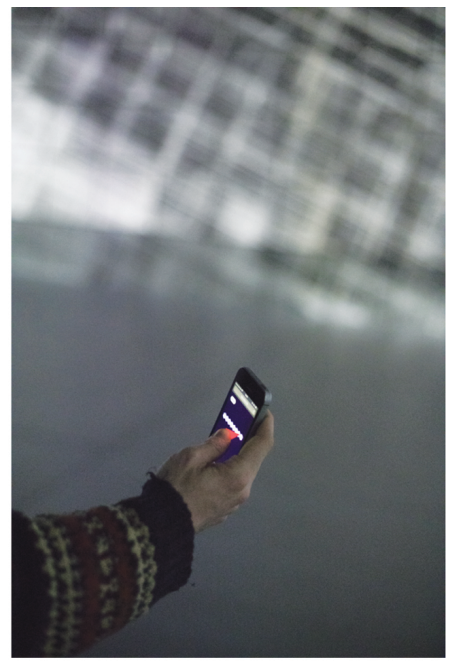

(b)

Figure 1: (a) and (b): Where am I?, 2017, Research \& Creation Workshop under the direction of Dominique Cunin (EnsadLab / Reflective Interaction). Experimentation of video-mapping and collective interaction with smartphones, La Gaîté lyrique, Paris, December 2017, with the support of the Chaire Arts et Sciences of the École polytechnique, the École nationale supérieure des Arts Décoratifs, and the Daniel and Nina Carasso Foundation. This workshop contributed to the development of Mobilizing.js (http://www.mobilizing-js.net), a programming environment for mobile screens, conceived by EnsadLab and aimed at artists and designers. Photos: Samuel Bianchini.

rise to economic advantages and therefore uses other than those of artistic creation, leading to appropriate legal and economic forms. The various actors can then distribute the potential gains in relation to their various disciplines, their respective contributions, and the field of application (execution) of the instrumentarium in question. Thus artists could retain rights for artistic applications, scientists could preserve them for scientific applications, and both could share the potential benefits from industrial transfers, negotiating on a case by case basis. Ultimately, such economic advantages relate to the instrumental stage, the research stage that is collective, most often multidisciplinary, and that needs to be formalized in order to be shared, both during the work of development and during the use that is open to others. Once formalized and modeled, that stage increases universal practical knowledge and truly responds to the fundamental issues of research.

\section{Examples of Research \& Creation Projects}

Since this is, first and foremost, a question of practice-based research, it is essential to base our approach on examples. Several have already been presented in the previously-mentioned preliminary publication [15] as the Behavioral Objects project and its modular robotics kit (MisB Kit) ${ }^{22}$ or the software framework Mobilizing developped and used for many projects as the recent Research \& Creation Workshop Where am I, under the direction of Dominique Cunin (see Figures 1 (a) and (b)). However, we can briefly present another Research \& Creation project that corresponds to this approach.

In 2010, I was contacted by the French Alternative Energies and Atomic Energy Commission (Commissariat à l'énergie atomique et aux énergies alternatives - CEA) in Saclay, near Paris, to work with them on a project that would implement a result of their chemistry research on the treatment of surfaces. We developed a process to prepare glass surfaces in a way invisible to the naked eye - so that water falling on a surface would form a pattern, attracted by some zones and repelled by others. That process was driven very early on by an artistic project that was completed in 2016: Mourners (see Figure 2 (a) and $(b))$

\footnotetext{
${ }^{22}$ Cf. : http://misbkit.ensadlab.fr [accessed July 15, 2017]. This "Behavioral Objects" project and its modular robotics kit MisB Kit is also presented in another publication [21].
} 


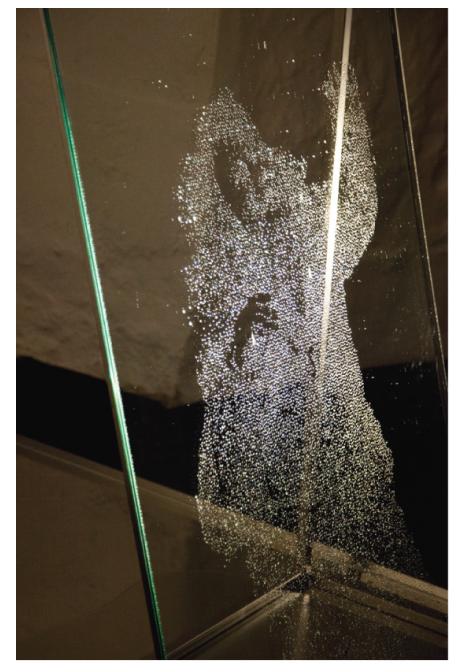

(a)

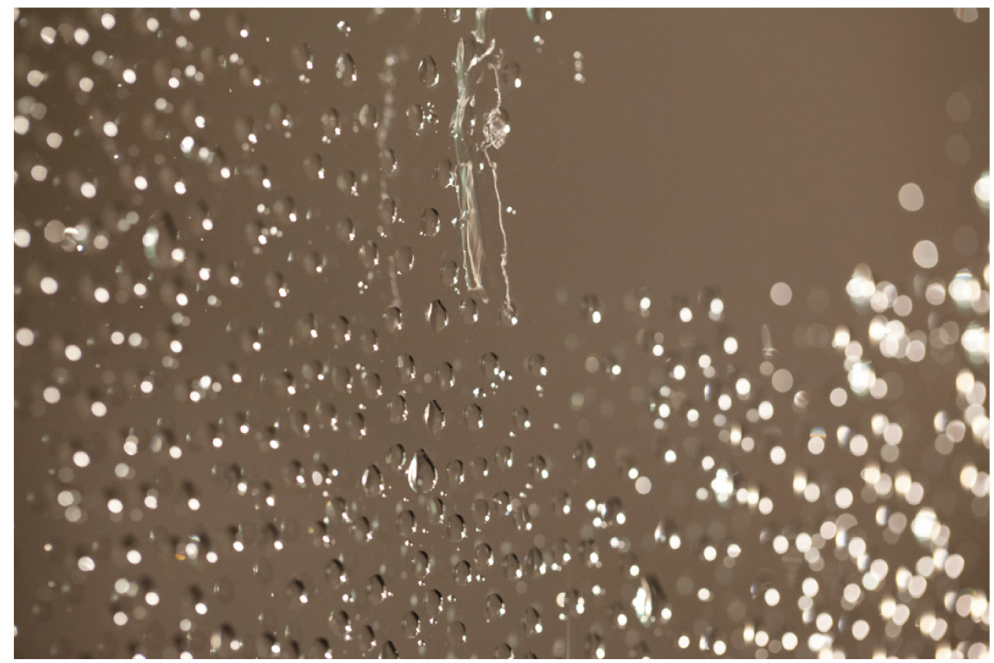

(b)

Figure 2: (a) and (b): Mourners, installation, 2010-2016. Samuel Bianchini with the collaboration of Pascal Viel (CEA). Collaboration on the technical process: Daniel Desforge (CEA) | Instrumental glassware: Bruno Coltrinari (CEA) | Collaboration on the surface chemistry: Geoffrey Barral (CEA) - Scientific mediation: Franois Bugeon (CEA) | Artistic mediation: Mari Linnman (3CA) Production assistance: Élodie Tincq | Assistance for creating the figures: Olivain Porry. Acknowledgements: Rémy Albert, Christophe Aubry, Cécile Baudin, Marc Billon, Patrick Champion, Michel Delarasse, Bruno Delomez, Michel De Sousa, Maud Gallois, Pascal Godon, Robin Guibal, Nassim Hanif, Olivier Kuster, Gilles Le Chevallier, Guillaume Le Chevallier, Franois Legrand, Clément Moussay, Arnaud Poirel, Alain Porcher, Mathieu Porchet, Jean-Marc Reymond, Jean-Luc Sida, Marie Vandermersch, Clarisse Viel. This project was created with support from the Saclay research center of the French Alternative Energies and Atomic Energy Commission (CEA Commissariat à l'énergie atomique et aux énergies alternatives), Diagonale (Université Paris-Saclay), and the Department of the Essonne. La Crypte, Orsay, November 2016. Photos : Samuel Bianchini.

The Mourners project employs the well-known phenomenon of drops of water finding their way down a window, but it controls the course of the drops as well as their production. Plates of glass of human size, positioned like stelae, let drops of water - emerging from a sort of water flute created for the installation - flow down their surface. The drops do not seem to move randomly toward the ground, but take meandering routes, following invisible paths, accelerating, decelerating to form sketches of human figures whose expressions are, in fact, conditioned by that process and materiality. Subtly lit, the glass plates rest on mirrors that encourage the play of reflections and gazes: they reveal faces and bodies, those of mourners on their surface as well as others seen through them or reflected on them, those of the viewers. Such subjects have, since antiquity, associated deep feeling and pretense, affect and representation. Pursuing that tension, here the sensitive meets the most advanced technology to communicate feeling, through absence or through transparency.

Based on an innovative dispositif and process, the artistic project also stimulated developments that required numerous experiments and iterations between means and ends. And those ends may be plural, because it is a practical potential of creation that is therefore produced and that can stimulate new projects, themselves sources of new developments, for example for the work At Present ${ }^{23}$ (see Figure 1 (a) and 3), created in 2017 in the wake of Mourners. A virtuous loop had been established.

\footnotetext{
${ }^{23}$ At Present, which required a rethinking of the process used in Mourners for typography, can briefly be described as follows: drops of water fall on a glass stele; they do not seem to be moving randomly, they wander, follow invisible bends and form letters and parts of letters; they provide glimpses of words, a sentence, the epitaph of a thinker, Félix Guattari.
} 
Based on multidisciplinary collaboration, it can also be shared, particularly with regard to the process that was created.

Other examples clearly demonstrate the potential of this approach. We can quickly present a few historic ones, focusing for the most part their instrumental innovation. Emmanuel Carlier, for example, who, for his work Temps Mort (1995) presented at the Lyon Biennale [22] that same year, began inventing, in 1993 - and in a direct line descending from Étienne-Jules Marey and Eadweard Muybridge - a process based on an apparatus for taking simultaneous photographs, in $360^{\circ}$, with a large number of cameras around the same scene (for example 36 cameras to have one every $10^{\circ} ; 70$ cameras in the case of Temps Mort). The series of photographs produced in this way made it possible to turn around an object frozen in movement. Used subsequently in videos and more minor films, Carlier's process was made hugely popular by the Wachowskis, who called it bullet time, in The Matrix. David Rokeby is also engaged in an instrumental research approach, carrying out, since 1982, computer

innovations for his Very Nervous System, collected in software, softVNS, that continues to be distributed for use by other creators, as Jean Gagnon describes [23]. In the same vein, one could retrospectively consider certain works or approaches by artists as pertaining to instrumental research, such as Dziga Vertov and his moving picture systems, and Sergei Eisenstein and his editing experiments and theories. Let us also recall Marcel Duchamp and his optical machine (Rotorelief) that even participated in the 1935 Concours Lépine; Pierre Schaeffer and Jacques Poullin (and their Phonogènes series, from 1951); Fujiko Nakaya for her Fog Sculpture process on which she began work in 1970 (patented in $1989^{24}$ ); the Vasulkas and their image synthesizers; and other devices like those of the Machine Vision series, ${ }^{25}$ begun in 1975; or even certain literary tech-

\footnotetext{
${ }^{24}$ System for making a cloud sculpture from water-fog, Patent \#1502386, Cf. Fujiko Nakaya [24].

${ }^{25} \mathrm{Cf}$. Catalog of the 3ème Biennale d'art contemporain de Lyon: installation, cinéma, vidéo, informatique, Op. Cit., p. 132-133. Or the website of the Fondation Daniel Langlois http://www.fondationlanglois.org/html/f/page.php?NumPage $=423$ [accessed July 15, 2017]. According to Don Foresta, the Vasulkas "are artists' artists". That mise en abyme clearly reveals the capacity to be useful to other artists, and to the arts in general, through an instrumental and therefore transferable approach.
}

niques such as the cut-up employed by William S. Burroughs, after Brion Gysin; as well as works by Dan Graham, Piotr Kowalski, and, more recently, by Jim Campbell, Olafur Eliasson, Wim Delvoye, Rafael Lozano-Hemmer, Hubert Duprat, etc.

\section{Singularity and Sharing}

Creation is not the equivalent of research, but many artists nonetheless develop their own processes, their own techniques, their own instruments. While that step is necessary, it is not enough to qualify such an approach as research, strictly speaking. For that, artists must also translate the research to make it shareable, be it practically in instrumental form (instrument, apparatus, software, notation, protocol, etc.), and/or theoretically in the form of knowledge (theory [publication], patent, license [including public licenses], or any other specification or prescription enabling its use by others). On the other hand, while that effort at transmission must be underlined, it is in no way a guarantee of artistic quality; certain artists, such as Jeffrey Shaw, with his EVE project, may be major instrumental creators - of apparatuses, for example - without actually implementing all of their developments. Many artists may, however, consider that their instrumental research should not be shared, in order to preserve the singularity of their work in which it is used. They may also argue that the work of modeling and translation does not have to be their responsibility. One might object that it is a shame to see artists like Emmanuel Carlier being robbed of their research - especially by people from non-artistic fields, the cultural industries and advertising first among them - without the benefit of a return of any kind, while we know how hard it is to live from one's artistic production. When that return is lucrative, it would offer an alternative to the art market alone. Another kind of recognition is also possible, based on open source methods: by associating our names with these instrumental developments, when others take them up and use or modify them, they also ensure the dissemination of our names, and our egos, the incarnation of the distributed authority so precociously anticipated by Roy Ascott. ${ }^{26}$

\footnotetext{
${ }^{26}$ Roy Ascott introduced the "distributed author" notion during the creation of his project The Pleating of the Text: A Planetary Fairy Tale in 1983 during theElectra exhibition at the Musée d'art moderne de la Ville de Paris. See, for
} 


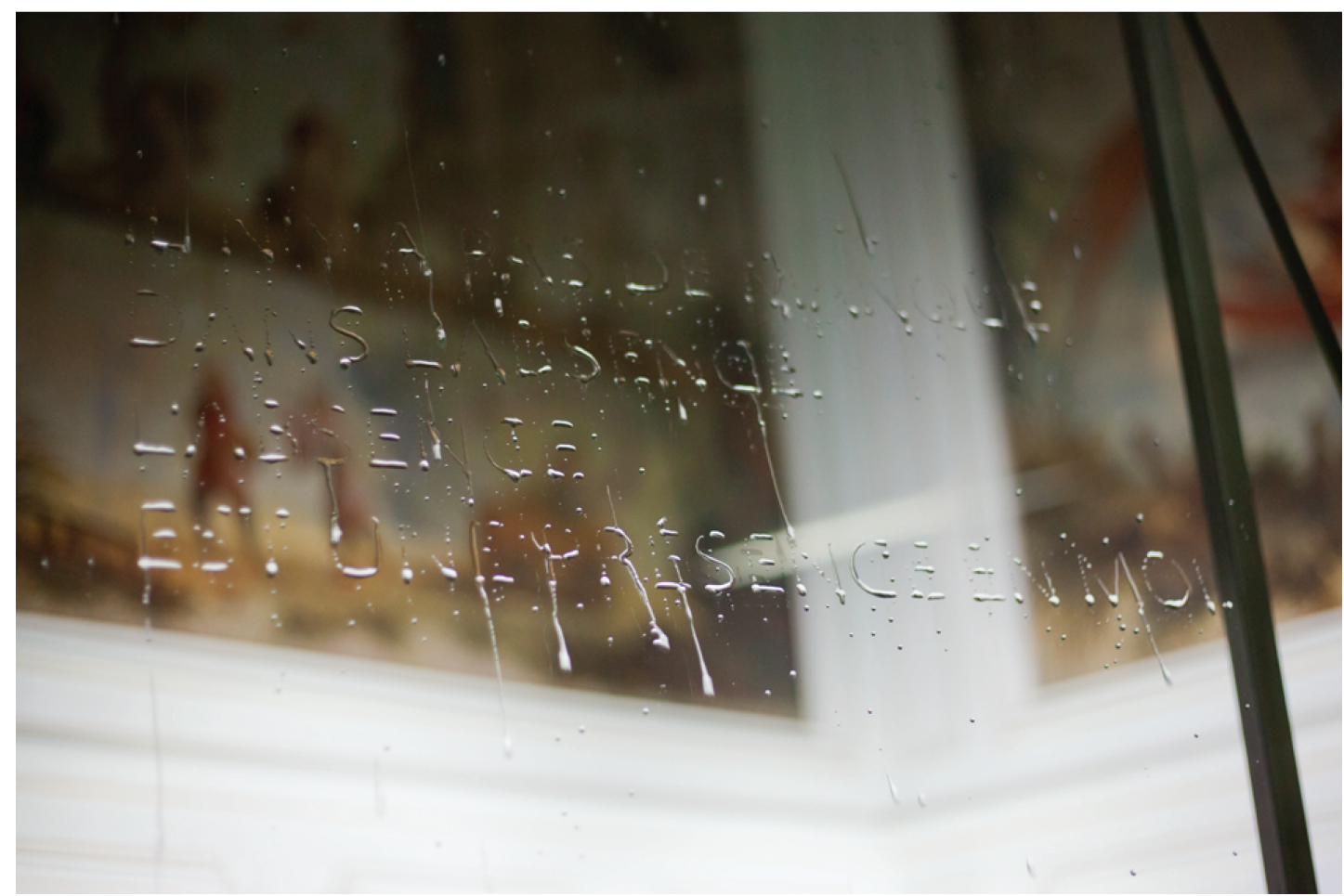

Figure 3: At Present (Félix Guattari), installation, 2017. Samuel Bianchini with the collaboration of Pascal Viel (CEA). Collaboration on the technical process: Daniel Desforge (CEA) | Instrumental glasswork: Bruno Coltrinari (CEA) | Collaboration on the surface chemistry: Geoffrey Barral (CEA) — Scientific mediation: Franois Bugeon (CEA) | Production assistance: Élodie Tincq This project was created with support from the Fundamental Research Department of the French Alternative Energies and Atomic Energy Commission (CEA Commissariat à l'énergie atomique et aux énergies alternatives), the CEA-Saclay research center, and Le Diagonale Paris-Saclay. Curiositas Exhibition, Château de Button, Gif-sur-Yvette, May 2017. Photo: Samuel Bianchini.

Though these questions of the redistribution of authority (and of ego) may seem peripheral to the subject at hand, that is not in fact so. They inevitably become central, or rather permanent and diffuse, laden with unspoken expectations, each individual trying to subtly recoup their investment as quickly as possible, exploiting results while participating as little as possible in their development. As the head of a research team in a school of art and design, I am confronted on a daily basis with student-researchers and creator-researchers who, for the most part artschool trained, tend to focus on their own individual, short-term advancement, thinking that recognition results from a break with their institution: crediting a team and an institution in which part of the research work was accomplished would be tantamount to relinquishing part or their authority, and present-

example, the case of an artist who creates artifacts, such as Golan Levin. ing themselves as subservient or even student-like in the eyes of an art world that needs names, single unaffiliated signatures, individual geniuses. And so ensuring respect for credit where credit is $\mathrm{due}^{27}$ is a still a daily struggle that requires constant, ceaseless explaining about the validity of this approach in our context while highlighting a reality, a wager to be made: that by investing in research which is necessarily prospective and often complex and that calls for a collective, multidisciplinary approach, one can later benefit from the results and use them in a singular and original way. Fair's fair.

How can one use this research in a singular and original way? Through creation. On the one hand

\footnotetext{
${ }^{27}$ Such credits are essential: they give an account of the creators, the context, even the history of the production, thereby emerging as a sort of "pedigree" of the work. Their fair hierarchy does not challenge the authority of the artists; on the contrary, it redistributes it.
} 
because this research is usable, because instrumental, and, on the other hand, because it emerges from a need to create: it derives, as we have already seen, either from a creative project or from a desire to experiment. Creation is both an engine for and a result of research. There is, moreover, we repeat, no consecutive relationship between research and creation, but rather recursiveness, the one energizing the other, with, at the center, experimentation carried out according to requirements that may be scientific or technical, but are above all artistic. Because it is according to artistic criteria that the results will be judged in our community, which is at the convergence of practice-based research in art and professional artistic circles. Of course, if that research can also meet the scientific criteria established by that other community, then the multidisciplinary approach will emerge with increased stature. For there is, for scientists, another wager to be made: that of trusting artists. Artists' concerns, often laden with intense projection as to how the work will be received by an audience, can motivate an entire team, including the scientists. On the other hand, the artists must understand that they cannot expect everything from the sciences: there is no magical engineering that will satisfy their technical fantasies. And we must get beyond the too-frequent confusion among artists between science and engineering. Engineering is an extremely precious third-party that must be integrated into a subtle triangulation with the arts and the sciences ${ }^{28}$ at a time when technology has become central. A third party to everything, technology mediates and conditions every sphere of our societies. The instrumental situation that we describe contributes to investment there, not to conform to it, but to invent, rearrange, and orient those technologies and to propose alternative, sensitive, and emancipatory implementation methods.

While many of the needs and developments specific to a work participate in enriching the instrument, certain adaptations of the instrumentarium cannot become part of generic, instrumental, shareable, and modelable developments. A subtle arbitration is often necessary then to respect the appropriation of the instrument contributing a specificity to the work, guarantor of its originality. This is where one

\footnotetext{
${ }^{28}$ As such, it is not surprising that what enabled the development of EAT is without a doubt the position occupied by Billy Klüver, engineer, founder, and main person in charge of EAT.
}

of the problems in instrumental research arises: once the original means are shared, will they not they confer a "family resemblance", a similar technique, to all of the creative projects that employ them? For that reason, it seems important to be able to appropriate research in a singular fashion while being vigilant (research directors in particular) as regards generic developments in the service of a community (or even of all) and singular developments for an equally singular work. ${ }^{29}$ Though it is here a question of singularity, one must nonetheless take into account the fact that singularity is not necessarily the product of a single individual, but can also be the product of a collective. Alongside the pursuit of singularity, it is also essential to defend new artistic practices, some of which fall under the concept of distributed authority, accepting that the creations are part of shared research by defending and citing that research.

Another difficulty still needs to be discussed: how to do research for the non-allographic arts, the autographic, one-stage arts? Through the prism of our approach, what is, for example, research in painting? Despite the fact that the practice of such arts usually occurs in one stage, it seems possible to loosen and break those practices into stages in order to investigate them better, focusing on a preparatory, experimental stage requiring the development of news ways of working, new means. And so a research stage prior to creation, to implementation, can be imagined, as if we were "allographing" a technique in order to bring it into research. In painting, it could, for example, relate to pigments, media, principles of composition, "stratification" of layers, touch, transparency, etc. Of course many painters integrate these concerns, more or less intuitively or rationally. However, do they seek to systematize or model those efforts - to any extent - in order to share them through an instrumental approach and/or a theorization of their practice? These artists, to make their exploration public, could exhibit their path through a series of works, which are so many steps or paths or declensions. ${ }^{30}$ Such works embody original exploration that can be ex-

\footnotetext{
${ }^{29}$ See for example the creative projects carried out alongside the development of our modular robotics kit, the MisB KIT, at EnsadLab, Op. Cit.

${ }^{30}$ One could, for example, think of Robert Ryman or Gerhard Richter, but those examples must be relativized because those artists also published texts about their practice, which is probably revealing with regard to the "research" dimension of their approach [25] [26].
} 
perienced aesthetically when they are contemplated, but they are not intended to share their means in other ways, in theory or in practice. Or it could be via second parties: theorists, critics, journalists, etc. who, to a certain extent, can accompany the works and offer them another form of visibility or understanding, and, sometimes, an "instrumental" scope within their community of peers - artists - who can base themselves on that work to develop their own.

\section{Making the Work Public: Exhibition, "Publicizing" and "Art Transfer"}

Research, as already constituted in every discipline, necessarily includes a sharing dimension: it has the vocation of increasing universal knowledge, even if that means questioning past knowledge. For research in art, that knowledge is practical and must be able to be embodied, conveyed, and published in ways that cannot be held only to the standards of academic publications. Publication must be understood in its most basic sense: to make public. The arts are not at all lacking for means of making public, starting with exhibitions. Rethinking the multiple forms of publication and publicizing is essential and strategic when considering the development of research in art and its social, even political impacts. And, in return, that investment can also enable a reevaluation of how to make art public, beyond the usual methods. ${ }^{31}$ While creations implementing instrumental research and developments are, in fact, good vehicles for publicizing - if only because they can be exposed - many kinds of publicizing, of sharing, can take place on the basis of instrumental research itself. Thus, transfer, in the industrial as well as the more broadly societal sense, can mainly be achieved starting from that stage of research and its instrumental production.

\footnotetext{
${ }^{31}$ For example, what would a "poster session" be like for the arts, revisited by the arts? Keeping in mind that poster sessions are usually a meeting time organized during major academic conferences, with large posters synthesizing research, like those that can be found in the corridors of experimental science or engineering science laboratories In front of every one of the posters, researchers associated with the work in question are present to address any questions or comments. As supports for information as much as discussion, such posters enable the rapid launching of scientific discussion.
}

This two-stage, or rather two-state organization - so as, once again, not to vectorize the whole can and must also be taken into account with regard to the resulting legal aspects, in particular in the drafting of contracts that the laboratory and the creator-researchers can sign with partners, both public and private. The same is true for contracts between researchers and their own institutions. Thus we distinguish the instruments, devices, technical chains, etc. invented for the project from their applications, in particular artistic. Rights, exclusive or not, can be ceded for applications, sometimes with restrictions on one or more fields of application. For example, an art research laboratory may retain the exclusive right of application in the artistic field, but relinquish its rights to industrial applications, detailing the terms, as is usual. In any case, the art research laboratory, like all researchers in these disciplines, must not relinquish their exclusive rights to the instruments that they invent and that materialize their research, otherwise they will lose all of the benefits, whether those be the knowledge and expertise acquired and implemented or the possibilities for future development and creation.

Being practice-based, research in art focused on an instrumental dimension is also a source of practice, it comes from practice, and it stimulates practice: indeed, it is constituted by and for practice. Though this research is developed by a community for that community, as art - or as part of artistic projects - it is inherently concerned, unlike the sciences, with how it will make itself public. It does so, naturally, by being exhibited. But at a time when there is more and more talk about fablabs, open source and now open innovation, makers, etc., the aesthetic experience is no longer necessarily that of "finished products", but can also emerge from practical experience. Though not demonstrations, the works emanating from such research processes particularly encourage an examination of the original progression of their production, the practices of which they are the fruit. Some of them can even become "practicable" [27], offering the test of their conditions as an aesthetic and practical experience. Practice is not the custom, it does not conform to the rules in force, but invents itself in action. Far from the "producer/consumer", "transmitter/receiver" dichotomies, practice represents an intermediary space, a porous space where the roles can be open, permeable, even redistributed, in particular for art and its research, stronger thanks to 
its public vocation.

Sharing and stimulating new practices with sensitive and reflective vocations in tune with the future of our societies by increasing the knowledge about and conditions of such practices; such may be one of the major goals of Research \& Creation as we conceive of it. While art has for several centuries ${ }^{32}$ been focused on the figure of the artist embodied by his mark on unitary and perennial objects, research in art requires a rethinking of the organization of our institutions to teach creators to say "we" without denying their "I", and even enhancing its status, albeit differently. This is not an easy task. To meet that need, our institutions must take into account new ways of doing things together and producing something shared, producing a commons. Because, indeed, if it is a question of doing and practicing together, our communities are permeable and do not stop at the doors of the studio or the lab: sharing can take place between peers, with experts in other disciplines, with amateurs, and with an audience. Art, experimental as well as experimentable, is a vector of porosities and connections that make it possible to build audiences and, more broadly, society. ${ }^{33}$

Funding: This research received no external funding.

Conflicts of Interest: The author declare no conflict of interest.

\section{References}

[1] Imbert J. (1998). Une nouvelle place et un nouveau rayonnement pour les écoles d'art en France (A new place and a new influence for art schools in France). Report for the French Minister of Culture and Communication, February 1998.

[2] Bianchini S. (Ed.). (2009). Recherche \& Création. Art, technologie, pédagogie, innovation, Montrouge, Burozoïque and École nationale supérieure d'art de Nancy; republished in electronic format (2012), Paris, Art Book Magazine, www.artbookmagazine.com [accessed July 15, 2017].

[3] Archer B. (1979). Design as a discipline. Design Studies, 1, 17-20.

\footnotetext{
${ }^{32}$ Albrecht Drer's founding act - his head-on self-portrait painted in 1500 - comes to mind, as do the major figures of modern and contemporary art whose names have also become labels or brands.

${ }^{33}$ Echoing the book by Didier Debaise, Xavier Douroux, Christian Joschke, Anne Pontégnie, and Katrin Solhdju (Eds.) [28].
}

[4] Findeli A., Coste A. (2007). De la recherche-création à la recherche-projet : un cadre théorique et méthodologique pour la recherche architecturale. Lieux communs, 10, 139-161.

[5] Frayling Ch. (1994). Research in Art and Design. Royal College of Art Papers, 1(1).

[6] Gosselin P., Le Coguiec É. (Eds.). La recherche création, pour une compréhension de la recherche en pratique artistique, Québec, Presses de l'Université du Québec, 2006.

[7] Web site edited by Boissier J.-L. and Terrier L. http://www.rvdv.net/vincennes/?page_id=13 [accessed July 15, 2017].

[8] Djian J.-M. (Ed.). (2009). Vincennes : Une aventure de la pensée critique, Paris, Flammarion.

[9] Lancri J. (2001), Modestes propositions sur les conditions d'une recherche en Arts Plastiques à l'Université, Plastik, 1, Paris, Éd. Université de Paris I Panthéon-Sorbonne, CERAP, 107-116.

[10] Da Silva J. (2004), La recherche en arts plastiques, entre réflexion critique et réflexion du créateur. oeuvré à plusieurs. Plastik, 4, Paris, Éd. Université de Paris I Panthéon-Sorbonne, CERAP, 204-213.

[11] Passeron R. (1989). Pour une philosophie de la création. Paris, Klincksieck, Coll. d'Esthétique.

[12] Shitao (1984). Les propos sur la peinture du Moine Citrouille-amére (Sayings on Painting by Monk Bitter Gourd), French translation and commentary by Pierre Ryckmans, Paris. Hermann, coll. Savoir sur l'art.

[13] Bayle L. and al. (1992). Recherche et création, vers de nouveaux territoires, Paris, Ircam Centre Pompidou.

[14] Latour B. (1985). Les "vues" de l'esprit, originally published as the introduction to Latour B. \& De Noblet J. (Eds.), Culture Technique. Les "Vues" de l'Esprit, 14, 4-30. Republished in Bougnoux D. (Ed.). (1993). Sciences de l'information et de la communication, Paris, Larousse, 572-596. Accessible online on Bruno Latour's website: www.bruno-latour.fr [accessed July 15, 2017].

[15] Bianchini S. (2015). Towards Organogenesis: For an Instrumental Approach in Research in Art. Media-N, Research-Creation: Explorations. In Chapman O., Paquin L.-C., Poissant L., Sawchuk K. (Eds.). Journal of the New Media Caucus, 11(3), http://median.newmediacaucus.org/researchcreation-explorations/towards-organogenesisfor-an-instrumental-approach-in-research-in-art [accessed July 15, 2017].

[16] Stiegler B. (2012). De la misère symbolique, Paris, Flammarion, Coll. "Champs-Essais". Combined reissue of Stiegler B. (2004). De la misère symbolique 1. 
L'époque hyperindustrielle and Stiegler B. (2005). De la misère symbolique 2. La catastrophèdu sensible, Paris, Galilée.

[17] Latour B. (2000). Morale et technique : la fin des moyens. Réseaux, 100, 39-58.

[18] Goodman N. (1968 revised in 1976). Languages of art. An approach to a theory of symbols, Hackett Publishing. Book published in french in 1990 and in 1998 : Langages de l'art: Une approche de la théorie des symboles, Nîmes, Jacqueline Chambon, presented and translated by Jacques Morizot.

[19] Goodman N. (1984). Of Mind and Other Matters, Cambridge, Harvard University Press. Translated of the two first chapters in french with a postface by Cometti J.-P. and Pouivet R. (1996). L'Art en théorie et en action, Paris, Gallimard, Coll. "Folio Essais".

[20] Bianchini S. (2009). Exp. - De l'expérimental à l'expérimentable. In During E., Jeanpierre L., Kihm Ch., Zabunyan D. (Eds.), In actu - De l'expérimental dans l'art, Dijon, Les presses du réel, 285-304. Published in Spanish (2012): La experimentacin estética: público y artista en las instalaciones. In Perales Blanco V., Creatividad y discursos hipermedia, Murcia, Ediciones de la Universidad de Murcia, 81-100, translated by Verónica Perales Blanco.

[21] Bianchini S., Bourganel R., Quinz E., Levillain F., Zibetti E. (2015). (Mis)behavioral Objects, Empowerment of Users vs Empowerment of Objects, in Bihanic (Ed), Empowering Users Through Design, Interdisciplinary Studies and Combined Approaches for Technological Products and Services, Berlin, Springer, pp. 129-152.

[22] Exhibition catalog (1995). 3ème Biennale d'art contemporain de Lyon : installation, cinéma, vidéo, informatique, Paris, Réunion des musées nationaux.

[23] Gagnon J. (2016). Viewer-Instrumented Play: Very Nervous System by David Rokeby. In Bianchini S. and Verhagen E. (Eds.). Practicable. From Participation to Interaction in Contemporary Art, Cambridge / London, MIT Press, 493-501.

[24] Duguet A.-M., Nakaya F. (2012). Brouillard, Paris, Anarchive.

[25] Ryman R. (2009), Critical Texts since 196\%. Colaizzi V. and Schubert K. (Eds.), Santa Monica, Ram Publication.

[26] Richter G, Obrist H.-U. (1995). The Daily Practice of Painting: Writings 1961-200\%. London, Thames \& Hudson.

[27] Bianchini S. and Verhagen E. (Eds.). (2016). Practicable. From Participation to Interaction in Contemporary Art. Cambridge / London, MIT Press.
[28] Debaise D., Douroux X., Joschke Ch., Pontégnie A., Solhdju K. (Eds.). (2013). Faire art comme on fait société - Les Nouveaux commanditaires. Dijon. Les presses du réel.

\section{About the Author}

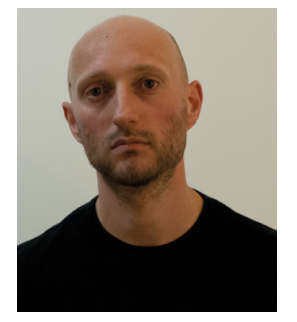

Dr. Samuel Bianchini is an artist and associate professor at the École Nationale Supérieure des Arts Décoratifs - Paris (EnsAD) / PSL Research University, Paris. Defending an "operational aesthetic," he works on the relationships between the most forward-looking technological "dispositifs", modes of representation, new forms of aesthetic experiences, and sociopolitical organizations, often in collaboration with scientists and research laboratories in the natural sciences and engineering.

His works are regularly shown in Europe and around the world: Nuit Blanche Toronto 2016, Waterfall Gallery (New York), Medialab Prado (Madrid), Kunsthaus PasquArt (Biel), Art Basel, Stuk Art Center (Leuven), Fiac, Centre Georges Pompidou (Paris), National Museum of Contemporary Art (Athens), Jeu de Paume (Paris), Laboratoria (Moscow), space_imA and DuckWon Gallery (Seoul), Centre pour l'Image Contemporaine (Geneva), ZKM (Karlsruhe), etc.

Samuel Bianchini defended his PhD thesis (from Université Paris 1 - Panthéon-Sorbonne) in an art center (The Palais de Tokyo in Paris) with a solo exhibition. He is now the Head of the "Reflective Interaction" research group at EnsadLab (the research laboratory of the École nationale des Arts Decoratifs), and the Co-Director of the Chaire Arts et Sciences Chair recently founded with the École Polytechnique and the Daniel and Nina Carasso Foundation.

Closely related to his research and artistic practice, Samuel Bianchini has undertaken theoretical work, which has led to numerous publications with, for example, Éditions du Centre Pompidou, MIT Press, Analogues, Media-N - Journal of the New Media Caucus, Hermes, Les Presses du Réel, Springer, etc. He recently co-edited, with Erik Verhagen, Practicable: From Participation to Interaction in Contemporary Art, MIT Press, 2016, with Emanuele Quinz, Behavioral Objects 1 - A Case Study: Céleste Boursier Mougenot, Sternberg Press, 2016, and, with Mari Linnman, À Distances - oeuvré dans les espaces publics, les Presses du réel, 2017. 